\title{
Reducing loneliness among older people - who is responsible?
}

Axel Ågren and Elisabet Cedersund

The self-archived postprint version of this journal article is available at Linköping University Institutional Repository (DiVA):

http:// urn.kb.se/ resolve?urn=urn:nbn:se:liu:diva-153334

N.B.: When citing this work, cite the original publication.

Aggren, A., Cedersund, E., (2018), Reducing loneliness among older people - who is responsible?, Ageing \& Society. https:// doi.org/ 10.1017/ S0144686X18001162

Original publication available at:

https:// doi.org/ 10.1017/ S0144686X18001162

Copyright: Cambridge University Press (CUP) (HSS J ournals)

http:// www.cambridge.org/ uk/ 


\title{
Reducing loneliness among older people - who is responsible?
}

Axel Agren and Elisabet Cedersund. Department of Social and Welfare Studies (ISV), Division Ageing and Social Change. Linköping University. Norrköping.

Corresponding author. Axel Agren, axel.agren@liu.se +46735593920

\begin{abstract}
In the Swedish news-press, loneliness among older people is presented as a severe problem that needs to be solved. The issue of who is responsible for reducing loneliness and how this responsibility is designated is, however, rarely discussed. In this study, we have analysed how responsibility is designated and constructed in articles from the Swedish news-press. Focus has been on identifying responsibility in discourses proceeding from the concept of subject positions. This concept has enabled analysis on how responsibility is negotiated and who is positioned as a responsible actor with the ability to perform actions that reduce loneliness. Three dominating discourses were found. In the discourse of responsibility within politics and the welfare state, the responsibility is both self-taken and designated to other institutions held responsible for not initiating sufficient measures to reduce loneliness. In the discourse of responsibility within societal and evolutionary perspectives on loneliness, developments beyond the individual's control are considered to contribute to loneliness. At the same time "we" in "society" are considered capable of reducing loneliness, thereby constructing individuals as responsible actors. Within the discourses of responsibility within senior organisations, both senior organisations and people who participate in activities are constructed as responsible actors. In conclusion, the responsibility for reducing loneliness is, apart from the discourse on senior organisations, designated to those working with older people.
\end{abstract}

Keywords: Ioneliness, responsibility, news-press, subject positions, discourses 


\section{Introduction}

When reading newspaper articles on loneliness from various countries statements such as "Ioneliness is as deadly as smoking 15 cigarettes a day", "Loneliness is killing us - we must start treating this disease" and "Loneliness "'forces older people into hospitals'" are regularly occurring (O'Grady, 2015; Monbiot, 2014; Gentleman, 2016). Headlines like these indicate that something has to be done in order to reduce loneliness. The issue of who is designated responsibility for reducing loneliness and how is, however, seldom addressed either in public debates or in research. Studying the topic of responsibility may bring insights into the kind of phenomenon loneliness among older people is considered to be (see Loseke, 2003). Is it an issue that the individual, the family or the immediate neighbourhood has to deal with? Is it an issue for non-profit organisations and civil society or is it a matter for the welfare state and institutions on a national level or local politicians within a region, a city or an entire society? Focusing on the topic in this way may bring insights into who is considered to be responsible and what levels of society are involved in the issue of loneliness among older people, thereby addressing whether the responsibility to reduce loneliness is constructed as a structural or an individual issue. Furthermore, studying this issue leads to understanding how older people are constructed with regard to their responsibilities, roles and positions in contemporary society and relates to one of the major issues of critical gerontology; what role older people have in the modern welfare society (Townsend, 1981; Estes, 1979).

According to Solin and Östman, (2015), the term responsibility is often assumed to be generally understood. The term is, however, complex partly due to its multiple and even contrasting meanings. The designation of responsibility can be used to blame someone for causing an intolerable situation, but may equally well refer to responsibilities associated with certain positions in society or to a person deemed to be trustworthy. Responsibility may consequently imply both moral and legal dimensions. Jolanki (2015) states that studies of responsibility entail a view of people as agents with the opportunity and ability to choose between different alternative ways of thinking and acting.

In this article, the focus will be on how the responsibility for reducing loneliness among older people is constructed in the Swedish news-press. There are several motives for studying the mass media and the Swedish news-press in particular. Media portrayals can be seen as 
illustrating cultural understandings of ageing (Gilleard and Higgs, 2007), which affect implicit and explicit attitudes towards older people (Kessler et al., 2004). How older people are constructed in the mass media has an influence both on the way older people are treated in their social environment and how social policies are formulated (Fealy et al., 2015; Koskinen et al. 2014), and also on the behaviours and evaluations of older people's own life situations (Pikhartova et al., 2016).

Studying older people's loneliness in the Swedish context is of particular interest for two major reasons. First, loneliness is often described as being a major issue in Swedish society, where Swedes are described as lonely people and that Swedish loneliness is something unique and a central part of the development of the Swedish welfare state (Berggren and Trägårdh, 2015). Second, Sweden is generally perceived as a universal welfare state with high taxation enabling universal care, education and social services, thus, often described as a unique society in an international comparison (Bengtsson, 2010). It could therefore be assumed that reducing loneliness among older people is a matter for the Swedish welfare state. Yet studies reveal an increase in privatisation and cutbacks in provision and a parallel increase in informal caregiving by people who help family members, relatives and neighbours (Warburton and Jeppsson Grassman, 2011). Also, in contrast to the widespread idea of the Swedish welfare state's high degree of responsibility, Berggren and Trägårdh (2015: 44-7) argue that NGOs have played a significant role in Swedish society for hundreds of years.

\section{Aim}

The aim of this study is to analyse how the responsibility for reducing loneliness among older people within the context of the Swedish news-press is constructed and designated. Relating to this aim, the following questions will be addressed in the study:

1. How is the responsibility for reducing loneliness among older people constructed? Is the responsibility seen as a moral or legal task? Is responsibility connected to blame, implying that individuals, organisations or institutions have failed in relation to expectations of a certain position? Or is it designated to those considered to be trustworthy?

2. Who is made responsible for reducing loneliness among older people? Are older people, individuals, families, institutions or organisations considered to be responsible for reducing 
loneliness among older people? This leads to the question of whether responsibility is considered to be an individual issue or a collective endeavour.

\section{Background}

\section{Responsibility - a central concept within critical gerontology}

Responsibility for the well-being of older people can be understood through the concept of Aging Enterprise (1979), formulated by sociologist Carroll Estes. The concept, which, to some extent, has been criticised for underscoring macro- and structuralist perspectives and of stressing state-led dependency at the expense of dependency on the market (van Dyk, 2014; Phillipson, 1998), is used to examine the relationship between social policy and all the programs, organisations, industries, providers and others "that serve the aged" and how these contribute to socially construct older people as a problem. According to Estes, various social forces such as low income, stigmatisation, exclusion from arenas of social life, asymmetrical relations between older people and professionals contribute to socially produce dependency among older people (Estes, 1999: 135-38). On the other hand, more recent studies have revealed that there is a tendency in contemporary societies to construct the individual as responsible for remaining active and ageing successfully (Ekerdt, 1986; Rozanova, 2010). According to van Dyk's (2014: 96) overview of critical perspectives on the concept of active ageing, it is considered to construct "disciplinary pressure to correspond to the new images of ageing". Laliberte Rudman (2006) view the concept of active ageing as imbedded in a neoliberal rationality where individuals are seen as being offered ways to free themselves from "oldness", which, however, results in new types of social obligations. In addition, care of older people is to an increasing extent constructed as a matter for the family (Timonen, 2016; Wilinska and Cedersund, 2010). According to Jolanki (2015), increased responsibility for individuals and family may be understood as an attempt to empower citizens and strengthen family ties. On the other hand, this process can be understood as an ideological shift putting more responsibility on the individual and family (Jolanki, 2015) and as a result of the withdrawal of the welfare state (Rozanova, 2010). Thus, there can be said to be a fine line between autonomy and independence on the one hand and dependency on the other, which in turn may have an impact on what responsibility older people are considered to have regarding loneliness and the provision of social relations. Timonen points to this divide, which he defines as: "the paradox of (in)dependence: exhorting independence among a 
group of people who are simultaneously construed as dependent and vulnerable." (Timonen, 2016: 1-2). The complexity of responsibility for older people is highlighted by Magnus Nilsson (2008), when he found that the constructions of older people as a category in the news-press, in texts from a seniors' organisation and a governmental report were not merely a process of exclusion and constructions of "the others", as he emphasises that older people are constructed as an object of "our" national responsibility. This is summarised in Nilsson's concept of including othering, since older people are "our others", "those who are talked about but who do not talk themselves." (Nilsson: 2008: 256).

\section{Research on responsibility for reducing loneliness among older people}

The specific issue of how the responsibility for reducing loneliness among older people is constructed has, to our knowledge, only been examined in a few studies. Uotila et al., (2010) found that older people are constructed as objects when alleviation of loneliness is discussed in the Finnish media. The authors found that the organisation of activities, collecting of money and the provision of care of older people was conducted by people other than older people. Another finding from their study, which also touches on the issue of responsibility, was that older people were represented as forgotten by society and that eldercare was described as inhuman. In the study by Schirmer and Michailakis (2015), societal changes and the transition from traditional to modern societies was seen as causing an individualistic society with less fellowship, leading to an increase in loneliness.

Research focusing on loneliness among older people has, consequently, only to a minor extent studied the issue of responsibility. Implicitly, however, the issue of responsibility is present in a vast amount of research studies from various disciplines, since a recurring understanding of loneliness among older people is that it is a psychological state that should be treated, reduced or alleviated (Mullins, 2007; Westberg, 2012). Victor et al. (2009: 35-7), state that studies on loneliness differ depending on the various philosophical traditions that prevail within social gerontology. Viewing loneliness as existing in "the real world" is, according to the authors, a positivist perspective where loneliness is seen as objectively measureable, which makes it possible to predict risks of loneliness and to develop interventions. Furthermore, Victor claims that research on loneliness in later life, implicitly and explicitly, departs from an understanding of "old age as a social problem" that needs to 
be solved (2015: 189). Rosendale (2007) claims that loneliness is commonly perceived as a social or personal deficit in need of correction, which is, according to the author, in line with current advancements of neuroscience and psychopharmacology, where the diagnostic process deconstructs suffering into a solvable problem. Loneliness is, consequently, understood as a symptom grouped with other symptoms and classified as a mood or adjustment disorder that may be treated with antidepressants. Thus, loneliness is viewed in a linear way where the problem is identified, treated and reduced (Victor and Sullivan, 2015: 255). This "pathological" view on loneliness is, according to Victor et al. (2009: 35-7), in line with the problem-oriented perspectives on ageing that have dominated gerontological research for decades, and is characterized by being rich on data but poor on theory (ibid: 31; Birren and Bengtson, 1988).

\section{Conceptual and theoretical framework}

In the present study, we view the concept of responsibility as a complex concept which is negotiated and constructed through communication within the context of the Swedish newspress. Particular focus is on how responsibility for reducing loneliness among older people is constructed in discourses. We view discourses as certain ways in which a phenomenon or issue is talked or written about and understood, which is dependent on cultural, historical and societal contexts (Burr, 2003: 3-4). Consequently, we proceed from an understanding of discourses as dominating ways in which, in this study, the responsibility for reducing loneliness among older people is communicated in written texts from the Swedish newspress. Studies on responsibility in discourses, can, according to Solin and Östman (2015), be conducted by carefully examining details in language and contexts in order to analyse how responsibility is negotiated regarding roles, rights and duties in relation to positions in society. To conduct a study with this focus the concept of subject positions has been given a prominent role in the analysis (Edley, 2001; Wetherell and Edley, 1999). According to Edley (2001: 209), Althusser (1971) was influential in his works on how people were positioned as "subjects" as a result of ideologies. Laclau and Mouffe's perspective on the concept of subject positions (2001: 115) is that the subject is not the basis for social relations, since the subject is embedded in discursive conditions of possibility. Since the 1990s, the concept of subject position has been adapted within discursive psychology with emphasis on how people position themselves and others within discourses (Edley, 2001; Wetherell and Edley, 1999). 
This use of the concept subject position can be seen as in line with overall perspectives of discursive psychology, focusing on how people in interaction use available discourses in negotiating representations of the world and how selves, emotions and thoughts are shaped and transformed (Winther Jørgensen and Phillips, 2002: 7).

\section{Concept of proto-morality and the ability to choose}

The concept of proto-morality, developed by Bergmann (1998), is of relevance in relation to the focus of this study. According to Bergmann, proto-morality refers to discourse-internal moral features, which are called proto-moral because they do not capture the concrete communicative forms in which morality is organised and experienced in everyday life. These proto-moral features instead put the spotlight on structural aspects of any morality, which is accepted as an essential cultural form in a society at a specific time. Proto-morality can be understood in the following way: "As competent actors we act on the assumption that we are capable of choosing among alternative courses of action." (Bergmann, 1998: 284). When ascribing to others equal abilities as those we ourselves also believe to possess, others are viewed as fellow humans who can think and act in different ways. The assumption that others have the ability to choose among different actions is thus the premise for the designation of responsibility. There is a reciprocal effect in this communication, as the same principle is extended to ourselves. Furthermore, Bergmann (1998) states that this reciprocal attribution of responsibility for behaviour is the fundamental proto-moral level of any dialogue. Bergmann's concept is of relevance for this study as it provides insights into how responsibility is constructed in communication and how the view of others, and ourselves, as possessing the ability to choose also leads to attributing to others and to ourselves responsibilities to be able to act in certain ways.

\section{Method and material}

The empirical material for this study consists of articles from the Swedish news-press collected from the database Retriever (www.retriever.se). The search words used were the Swedish words äldre AND ensamhet, which in English translates to older people AND loneliness. The timeframe was limited to October 2016. The chosen timeframe has enabled us to acquire up-to-date and detailed insights into how the responsibility for reducing loneliness among older people was designated, constructed, negotiated and who was positioned as a 
responsible actor with abilities to choose from and carry out actions to reduce loneliness among older people. The specific month of October 2016 was chosen as this was the month in which The National Board of Health and Welfare released a national report on how all people receiving eldercare experiences the provided care, with loneliness being one of the issues raised (Socialstyrelsen, 2016).

40 articles from the Swedish news-press were found from this month by using the search words mentioned above. The total number of articles found was, however, 176 . The principles for exclusion were; duplicates, articles mentioning äldre and ensamhet in separate parts of the articles not referring in any way to loneliness and older people, and calendar event announcements. In addition, äldre in Swedish can also be a relational term meaning older than. Several of the articles found in the Retriever database used this relational meaning of the word, rather than focusing on older people. These articles were, therefore, excluded. In the Swedish context, the term äldres ensamhet is often used to describe the issue of Ioneliness among older people. Consequently, this term was also used when searching for articles in Retriever. These search words resulted in one additional article for October 2016 and was included as part of the empirical material for this study.

After having collected empirical material consisting of 40 articles from the Swedish newspress, we proceeded to analyse the material gathered. The analysis process will be described in detail below.

First, we read all articles to gain an overview and initial understanding of our material. In the second step of our analysis process, we developed a table for analysis, which was inspired by the works of Thompson (2000), who acknowledges the relationship between media and societal context, and the concept of media logic (Altheide and Snow, 1979), which emphasises that the kinds of methods, conditions and formats that are available within a mass media context which have implications on how events and phenomena are written about. Analytically, this was first done by sorting the articles in a table based on types of newspapers (geographical distribution area) and types of articles (Table 1).

Table 1. Types of articles and types of newspapers (geographical distribution area): 


\begin{tabular}{lccccccc}
\hline & News & Editorial & Debate & $\begin{array}{c}\text { Culture- } \\
\text { reportages }\end{array}$ & Chronicles & Reportages & Total \\
\hline Local & 6 & 1 & 5 & - & 2 & 1 & 15 \\
Regional & 12 & 1 & 2 & 2 & - & 2 & 19 \\
National & 2 & 3 & - & - & - & 1 & 6 \\
\hline Total & 20 & 5 & 7 & 2 & 2 & 4 & 40 \\
\hline
\end{tabular}

In the third step, we took into consideration the societal contexts addressed, dominant discourses and how responsibility is designated and constructed in the articles from the Swedish news-press. In this step, the initial emphasis was on identifying prevailing discourses, i.e. the dominant ways in which the issue of responsibility for reducing loneliness among older people is written about. Identifying types of societal contexts addressed helped to distinguish recurring discourses. In other words, identifying societal contexts recurrently addressed in the Swedish news-press provided insights on the societal contexts to which the issue of responsibility for reducing loneliness among older people was related. Thus, finding these dominating societal contexts served as the basis for identifying discourses within which the issue of responsibility was addressed in different ways. The three discourses identified were the following:

- Discourse of responsibility within politics and the welfare state

- Discourse of responsibility within societal and evolutionary perspectives on loneliness

- Discourses of responsibility within seniors' organisations

Following the analysis of identifying discourses, particular focus was, in the fourth step, on the types of individuals, collectives, organisations or institutions that were designated responsibility for reducing loneliness, how they were positioned as responsible actors and by whom. In this phase of the analysis process, the critical questions were:

1. Who: Who is made responsible for reducing loneliness among older people? Is it individuals, collectives, institutions or organisations that are considered to be responsible for reducing loneliness among older people? Is the responsibility to reduce loneliness a matter for older persons or other instances in society? Is it a collective or individual responsibility? 
2. Responsible actor: Who is considered to be a responsible actor with the ability to choose between and perform actions in order to reduce loneliness?

3. Societal context: What contexts of society are addressed when writing about the issue of responsibility for reducing loneliness?

4. Blame or trustworthiness: Is the responsibility connected to blame, implying that individuals, collectives, organisations or institutions have failed in relation to the expectations of a certain position? Or is the responsibility designated to those considered trustworthy? Is the responsibility based on moral or legal assumptions or both simultaneously?

How the articles were analysed and systematised based on the questions above is displayed in Table 2. The numbers assigned to each category in the tables are the numbers of the questions presented above. In order to provide a comprehensive overview of the news articles the table starts with article headline, type of article, newspaper, date and author, geographical distribution area and a quote.

Table 2. One example from the analysis-process:

\begin{tabular}{|c|c|}
\hline Article headline: & It is extremely difficult to exist without relationships \\
\hline Type of article: & Article within a thematic series. \\
\hline Newspaper, date and author: & $\begin{array}{l}\text { Helsingborgs Dagblad } 5 \text { Oct 2016. Hanna Welin, } \\
\text { journalist. }\end{array}$ \\
\hline Geographical distribution area: & Local. \\
\hline Quote: & $\begin{array}{l}\text { Involuntary loneliness, but also alienation, leading to } \\
\text { strong malaise. The feelings can come out as anxiety and } \\
\text { sometimes even as anger, panic reaction that is deeply } \\
\text { grounded, says Peter Strang. }\end{array}$ \\
\hline 1. Who is made responsible? & $\begin{array}{l}\text { Only implicitly as a responsibility for the individual. The } \\
\text { focus is on evolutionary developments and the } \\
\text { importance for the individual of being part of a } \\
\text { collective and having social relations. To a minor extent, } \\
\text { eldercare is considered to focus insufficiently on older } \\
\text { people. }\end{array}$ \\
\hline
\end{tabular}




\begin{tabular}{|l|l|}
\hline 1. Collective or individual? & $\begin{array}{l}\text { Neither. The individual is, however, described as } \\
\text { dependent on being part of a collective. }\end{array}$ \\
\hline 2. Responsible actor & $\begin{array}{l}\text { None. Not the individual since developments referred to } \\
\text { are considered out of the control for the individual. }\end{array}$ \\
\hline $\begin{array}{l}\text { 3. Societal context in focus in } \\
\text { the article: }\end{array}$ & $\begin{array}{l}\text { Focus is on evolutionary developments and on } \\
\text { individuals and loneliness as part of human existence, } \\
\text { dying patients and eldercare. }\end{array}$ \\
\hline 4. Blame or trustworthiness? & $\begin{array}{l}\text { No particular actor is blamed or singled out as } \\
\text { responsible. Partly, eldercare is considered to have too } \\
\text { little focus on older people. }\end{array}$ \\
\hline 4. Legal or moral? & $\begin{array}{l}\text { Mainly moral. One short reference is made to the } \\
\text { obligations of eldercare. The main focus is, however, on } \\
\text { moral dimensions as loneliness is an issue that should be } \\
\text { reduced, without referring to legal documents and } \\
\text { obligations. }\end{array}$ \\
\hline
\end{tabular}

Note: 1 . The numbers assigned to each category are the numbers of the questions given in the text (see the Method and Materials section).

\section{Results}

In this section we will present the results of our analysis on how the responsibility for reducing loneliness is constructed and designated in the Swedish news-press. Three discourses were found: discourse of responsibility within politics and the welfare state; discourse of responsibility within societal and evolutionary perspectives on loneliness; discourse of responsibility within seniors' organisations.

\section{Discourse of responsibility within politics and the welfare state}

In a debate article, a politician from the governing political party within the municipality in focus describes how the party he represents is actively working with prevention with the ambition of enhancing health and providing conditions for companionship and activity among older people. The article is a response to a previously published debate article formulated by a representative of an oppositional political party claiming that the governing party is not doing enough preventive work for older people:

\section{Excerpt 1:}


Working preventively gives citizens the opportunity to alleviate loneliness and meet new friends. The preventive unit in the care administration works actively with interest groups, the region, the Skåne sports-organisations, culture and leisure as well as volunteers with various types of activities and cultural experiences. [...] The staff work towards the goal of a good life, where the four cornerstones are social community, participation, physical activity and good eating habits. This provides the conditions for good health and postpones dependency. To meet and perhaps alleviate involuntary loneliness brings enjoyment of life and well-being. ${ }^{1}$

(Kristianstadsbladet, 8 October, 2016)

This excerpt displays what type of actors are designated as responsible and what types of activities are considered as contributing to reducing loneliness. Loseke (2003: 98) states that constructions of responsibility and solutions are based on how social problems are framed. Loneliness is here described as something possible to prevent through activity, healthy food, participation and socialising with others. These activities and investments are also held to improve health and postpone dependency. Thus, loneliness is framed as something negative that, like dependency and poor health, can be prevented through activities carried out by organisations within civil society and by welfare institutions. Hence loneliness is framed as being the opposite of activity, participation and socialising with others. This is in line with what previous research has found, where active and successful ageing are common policy terms in economically developed countries (Timonen, 2016: 6-7), where older people are encouraged and made responsible for ageing successfully in order to alleviate the "burden" of an ageing population (Lundgren and Ljuslinder, 2011). The notion of activity as important for older people is indeed prominent in the debate article from which the excerpt is taken. The responsibility for carrying out and planning the activities is, however, designated to the relevant organisations who provide the activities and not mainly to older people. Here, Estes' concept of Aging Enterprise (1979) becomes relevant, as it is those "that serve the aged" who are discussing the well-being and reduction of loneliness among older people. This was also highlighted by Uotila et al. (2010), where activities to reduce loneliness among older people were found to be carried out by people other than the older people.

When looking further on how responsibility is constructed, the author of the debate article, representing a political party, is positioning his own party and the organisations and institutions involved as trustworthy and as taking on the responsibility (Solin and Östman, 
2015) of reducing loneliness themselves. As Jolanki (2015) and Bergmann (1998) state, making others responsible is based on an agentic view, where others are considered to be capable of choosing, and, thus, being responsible for their actions. In Excerpt 1, the political party and the organisations and institutions involved are constructed by themselves as actors who are able to choose (Jolanki, 2015; Bergmann, 1998), as the author of the debate article is claiming that his own political party is taking various actions in order to work preventively, improve health and reduce loneliness among older people.

In the articles from the Swedish news press from October 2016, several newspapers were reporting on a national annual report based on a survey of older people's experiences of eldercare written by The National Board of Health and Welfare. These news articles follow a common structure on how this issue is written about. This makes the concept of media logic relevant, as formats and methods available at a certain time are considered to have an impact on how events are presented in media (Altheide and Snow, 1979).

The main gist of this report, regardless of geographical context, was that older people in general are very satisfied with the care provided, both within residential care and home care services. The news articles usually then go on to include quotes from either a person from The National Board of Health and Welfare, which is the institution that conducts the report, or from a head of unit from the high level of a municipality or within a local eldercare facility within a municipality. The articles then proceed to deal with the negative findings from the report, where anxiety and loneliness are described as commonly occurring. The excerpt below is one example of these types of articles:

\section{Excerpt 2:}

The National Board of Health and Welfare asked all older people who have homecare service or live in a nursing home how they feel and what they think about homecare services or their nursing home. The result shows that almost one in ten, nine percent, suffer from anxiety to various degrees. A little more, 15 percent, say they are often bothered by loneliness. "Many are very happy with their homecare or with their nursing homes, but there is a group that is not doing well and suffering from these inconveniences. What we now want is that the municipalities pay attention to these people and try to see what they can do for them", says Stina Hovmöller, Head of Unit at The National Board of Health and Welfare. What can the municipalities do about loneliness? "Loneliness can have many different causes, and older people may have different needs, but it is important that the municipalities 
talk to those who experience these inconveniences and try to improve the situation for that particular individual," says Stina Hovmöller.

(Metro-Värmland, 19 October, 2016) ${ }^{2}$

The excerpt displays several positive aspects of older people's experiences of eldercare. Thus this differs from common images of eldercare as being in crisis and lacking resources and staff not having enough time to meet older people (Markström et al., 2011; Gadson, 2003). Based on the results of the report presented in the article, it is revealed that despite these positive experiences, many older people are experiencing loneliness and anxiety. A noteworthy aspect of the excerpt is that responsibility is designated from one welfare institution (governmental, national level) to another (all local municipalities throughout Sweden). Despite being situated at different levels in society, this discussion is taking place between two types of institutions within the welfare sector. Similar to Excerpt 1, the municipalities are, in Excerpt 2, constructed as being able to choose between different actions (Jolanki, 2015; Bergmann, 1998) and The National Board of Health and Welfare considers that all municipalities should choose to talk to older people. Without specifically stating so, the municipalities are held responsible for not doing enough to reduce loneliness.

Excerpt 2 can be seen as differing from what generally characterises claims-making processes, where organisations or groups of people often address politicians, institutions or organisations higher up in the political hierarchy who are considered as not doing enough to alleviate the current problematic condition (Loseke, 2003; Spector and Kitsuse, 1973). Here, a state agency is designating responsibility to all municipalities. Thus, the designation of responsibility is going downwards in the hierarchy from national level to local municipal level.

In Excerpt 2, the only "voice" in the news article is that of a state agency. In several other news articles also addressing the national report, the voice of representatives from municipalities is presented, with this excerpt below as one example:

\section{Excerpt 3:}

- It is rewarding that there are still positive answers that show that our focus on values and meetings gives results. We come off well in comparison with both the country and the county, says head of unit within social services Ann-Gret Sillén. She points out that there is, however, an area that can be 
improved. We need to get better at enabling individuals to influence at what time they should receive help. [...] The user's sense of loneliness is also an issue that we need to put extra focus on.

(Oskarshamns-Tidningen, 31 October, 2016)

Although this excerpt is from the perspective of a municipality and not from a government agency as is the case with Excerpt 2, the two news articles (Excerpt 2 and Excerpt 3) have a similar approach. In both cases eldercare is described in positive terms but with loneliness and anxiety as the downside. The dividing line between the two news articles (from Excerpt 2 and Excerpt 3) is how responsibility is constructed, where responsibility, in Excerpt 2, is designated from a governmental agency to all municipalities, whereas the municipality designates responsibility to itself in Excerpt 3. The head of unit of social services within the municipality also admits that loneliness is an issue they should work more on, hence making themselves responsible for currently not doing enough. Although representatives from the municipality in focus point out what is being done to improve eldercare, it is, however, not specified how the work to reduce loneliness will be facilitated. Another difference between the two news articles is that Excerpt 2 addresses all municipalities in Sweden, whilst Excerpt 3 focuses on the same issue, but in a local context.

A majority of the articles within the discourse of responsibility in politics and welfare state are written by and discussed between politicians and representatives of professions who work with older people in different ways. Although these articles focus on the need for change, the tone is quite subtle. In one debate article, however, where the author is a representative of a seniors organisation, the tone is different and discontent with how older people are treated is emphasised:

\section{Excerpt 4:}

The municipality's budget for the coming years does not look bright for us older people. The plans for increased construction in the case of nursing-homes are not much to celebrate. The need is extensive today and the planned accommodations will not be enough. [...] You have also made cutbacks on activities at the various meeting-points by reducing staff. [...] Loneliness, malnutrition and dehydration are among the greatest diseases of our older people. Do not forget us!

(Norrköpings-Tidningar, 14 October, 2016)

The designation of responsibility in Excerpt 4 is primarily based on the idea that the municipality has failed to fulfil its obligations. The municipality is thereby constructed as the 
institution to blame (Solin and Östman, 2015) for its future plans regarding the care of older people, which are considered to be not fulfilling the needs of older people. The designation of municipalities as responsible can therefore be understood as a legal responsibility as focus is on the planning of the municipality's budget, which is a form of legally binding document that constitutes the basis for resources allocated to older people in need of care. Excerpt 4 is also noteworthy as it is the only article within this discourse where an article author writes from the position of "us", referring to "us" as a group of older people.

\section{Discourse of responsibility within societal and evolutionary perspectives on loneliness}

One issue that was addressed in the articles from the Swedish news-press was how modern society is in different ways contributing to causing loneliness and how loneliness may be regarded as an evolutionary part of being human. In 2014, a book on loneliness and togetherness as an evolutionary aspect of human life was published in Sweden. The book is often discussed in the public sphere in Sweden. In the excerpt below, taken from an article in the form of a report, the author of the book, Peter Strang, was interviewed:

\section{Excerpt 5:}

Voluntary loneliness can be nice and restful. Involuntary, however, directly dangerous, both for physical and mental health. Without relationships with others, people risk losing the grip.

"In eldercare, for example, there is so much focus on everything around, when the most important thing for old people is the relationships, eye contact, chat and body contact," he says. [...] The effects of loneliness and isolation that are involuntary are common to all humans. The explanation, he believes, is to be found in developmental biology. In order to survive on the savannah among the predators about 100,000 years ago, the primordial man needed to keep together. You were exposed to dangers if you left the group.

(Helsingborgs Dagblad, 5 October, 2016)

In Excerpt 5, loneliness is written about as something that can affect everyone, consequently constructing everybody as potential victims (Loseke, 2003: 80), and loneliness is only to a minor extent associated with ageing and older people. In the excerpt, the dangers of loneliness are associated with survival instincts stemming from ages when humans lived in hordes on the savannah and were dependent on others to survive. Thus, loneliness is 
constructed as an evolutionary issue and social relations presented as a crucial part of human existence. The report is, therefore, not a type of societal diagnosis where developments in modern society alone are seen as generating loneliness (Schirmer and Michailakis, 2015). Regarding the issue of responsibility, eldercare is seen as focusing on all other factors affecting humans and not focusing on the social needs of older people. The issue of responsibility within eldercare is, however, only mentioned as an example. The importance of social relations for the well-being of the individual is, nevertheless, particularly emphasised. Hence the individual is implicitly made responsible for the provision of social relations and the reduction of loneliness. Individuals who do not acquire these relations risk a direct threat to their mental and physical health. There is, therefore, an ambivalence regarding agency. On the one hand, evolutionary developments and essential needs which are considered to be beyond the individual's control are seen as causing loneliness. On the other hand, it is apparently the individuals' responsibility to acquire his or her own social relations, since the focus is solely on the individual's need for social relations and not having sufficient social relations is seen as a threat to mental and physical health.

In a chronicle under the headline "Loneliness makes you ill" the author refers, as do many other articles included in the present study, to the report conducted by The National Board of Health and Welfare, when claiming that loneliness is a serious matter:

\section{Excerpt 6:}

Being involuntarily alone is to endanger your health. Loneliness is an endemic disease we must start taking seriously. This week, The National Board of Health and Welfare published its annual report "What do older people think about elder-care".

An investigation reveals that the vast majority of older people are satisfied with the care they receive. So far so good, but there are other parts of the survey that are not as positive, 58 percent of the respondents say they are worried about loneliness. [...] The reason why we feel so bad because of loneliness has its bearing on evolution. The security of being part of a group has been such a powerful survival advantage, since over hundreds of thousands of years we have developed strong mechanisms for seeking community and avoiding loneliness. [...] Involuntary loneliness is widespread at all ages, but the older we become, the more vulnerable we become. This may be because a life partner or close friends have passed away or that the body is not capable of the same mobility as before, making it difficult to get out of the home to meet other people. But it is of course possible to change this. If 
we want to. If society wants to. An example is at the home care service in Vännäs in Norrbotten. There are ongoing attempts to offer extra hours of social support for some older people who feel alone.

(Arbetarbladet, 23 October, 2016).

In this excerpt, the designation of responsibility is more concrete as both individuals and society as a whole are considered capable of reducing the widespread loneliness "if we want to". Meanwhile, older people are considered as particularly exposed to the risk of feeling lonely, since loneliness is more distinctly related to changes which are considered to be agerelated, thereby constructing older people as more vulnerable to loneliness. Consequently, older people are constructed as being in need of help from "society". Since it is the responsibility of "society" and the "we" to help older people, there is a distinct division between those who belong to "society" and those who do not. The "we" and "society" are constructed as agents with the ability to choose between different actions (Bergmann, 1998; Jolanki, 2015), whereas older people are constructed as not possessing agency. The responsibility for reducing loneliness is thus constructed as a moral task, as emphasis is on how "we" should act, without referring to legislation. As demonstrated above, older people are not included in this community of people performing actions based on moral ideas.

\section{Discourses of responsibility within seniors' organisations}

To a minor extent, initiatives performed by individuals or smaller organisations were addressed in the articles from the Swedish news-press. In one news article, a local PRO ${ }^{3}$ organisation's boules section is written about:

\section{Excerpt 7:}

\section{Boules - an effective cure for loneliness in Nordmaling}

On Thursday, PRO Nordmaling's boules section had a season premiere in the association's indoor facility, where dozens of sprightly retirees meet every Monday and Thursday. [...] "Boules makes me

get out and I do not have to sit alone, meeting and talking to people for a while makes you feel content. And it gives a good exercise and is not at all difficult, so you can manage for a long time," says Greta.

(Västerbottningen, 13 October, 2016)

In the news article above (Excerpt 7), focus is on the organisation and what type of activities and solutions to loneliness the organisation provides. Compared with the other discourses in 
this study, this news article's focus is on activities within a specific local organisation within the sphere of civil society. Consequently, this news article focuses solely on the local organisation, with no complaints about certain societal and evolutionary developments causing loneliness. Furthermore, no welfare institutions are designated responsibility for reducing loneliness. There is, in other words, no counterpart to blame or to designate as responsible for reducing loneliness. Thus, it does not resemble what social problems theories describe as commonly characteristic for claims-making (see Spector and Kitsuse, 1973; Loseke, 2003). The responsibility for reducing loneliness is instead self-imposed by the organisation carrying out the activities, and by Greta who participates in the activities provided, in order to reduce her loneliness. The seniors' organisation is constructed as a reliable actor who can provide physical and social activities to reduce loneliness. The significance of the organisation's activities is further strengthened by the statements by Greta. Thus, both the organisation and Greta are designated responsibility and simultaneously ascribed agency.

\section{Discussion}

The aim of this article has been to study how the responsibility for reducing loneliness among older people is constructed and who is designated responsibility for the matter. The context studied has been the Swedish news-press. In this study we have found that the responsibility for reducing loneliness is designated and constructed in a variety of ways, mainly depending on the type of societal contexts addressed in the articles and the contexts (Thompson, 2000) and logics (Altheide and Snow, 1979) of the media. This was apparent as, in several articles, the report from The National Board of Health and Welfare constituted the basis for article authors arguing that loneliness among older people is widespread in society today and more specifically within Swedish eldercare. In news articles, mainly in the discourse of responsibility within politics and the welfare state, the report was in itself the main object of news. In debate articles within the same discourse the findings from the report served as an argument for the need to perform actions in order to reduce the extensive loneliness among older people. In chronicles within the discourse of responsibility within societal and evolutionary perspectives on loneliness the outcomes of the same report were used as a background to illustrate how development of an individualistic society has led to loneliness among older people becoming a widespread problem. Thompson (2000: 10-11) argues that the media 
produces, stores and distributes symbols perceived as meaningful for those who produce and receive them and that the structure of what is communicated and how it is communicated is affected by the societal context within which the media is embedded (Thompson, ibid). This also relates to the concept of media logic (Altheide and Snow, 1979), which underscores that the format of the media is considered to have an impact on how media material is organised and presented. Within the context of the Swedish news-press and the timeframe studied, the findings of the report from The National Board of Health and Welfare seemingly have the status of symbols perceived as meaningful for those who produce and receive the articles. In the Swedish news-press, within the studied timeframe, we found that the report had a significant structuring influence, as the articles were to a large extent organised around the findings of the report which highlighted widespread loneliness among older people. The focus on the report has implications on how the responsibility for reducing loneliness among older people is designated and constructed, since the report focuses on the societal context of eldercare which is organised and performed by Swedish welfare institutions. Consequently, loneliness among older people is understood as an issue of collective and institutional responsibility on the local and national level. It is, in other words, the institutions that are given agency, by themselves and by others, and viewed as capable of choosing between and performing different actions (Bergmann, 1998; Jolanki, 2015) in order to reduce loneliness.

Since the responsibility for reducing loneliness among older people is mainly related to politics and the welfare state, the task could seemingly be seen as based on legal obligations. Distinguishing between what is constructed as a legal or moral responsibility is, however, not a straightforward task. Loneliness among older people is, within the Swedish news-press, primarily described as an issue that has to be reduced, with no distinct references to legalisation. Consequently, although the responsibilities of municipalities are based on legal obligations, the responsibilities of these institutions are constructed as moral duties in the Swedish news-press.

The moral understanding of loneliness was further accentuated in several articles, as distinctions were made between involuntary and voluntary loneliness. Involuntary loneliness is the "bad" loneliness with severe consequences. Within this type of loneliness, the individual is not considered to be possessing agency and is therefore a victim of loneliness, with older people being described as particularly at risk of this type of loneliness. Voluntary loneliness, 
however, is constructed as "good" loneliness, as this type of loneliness is associated with peacefulness with a view on the individual as an agent possessing the ability to make choices (Westberg, 2012: 319-24). This kind of loneliness was not related to older people. This finding is in line with a study by Rozanova (2010), who argues that the media underline the significance of upholding an active lifestyle by contrasting "good" old age, which is related to independence, health and a socially active lifestyle, with "bad" old age which is associated with illness, physical and social decline and dependency (Rozanova, 2010).

\section{Responsibility and older people's positions in society - a complex issue}

In the introduction to this article we argued that studying the issue of responsibility for reducing loneliness may provide insights on how older people are constructed regarding responsibilities, roles and positions in contemporary society and relates to a key issue within critical gerontology: the role older people have in the modern welfare society (Townsend, 1981; Estes, 1979). Recurring findings within critical gerontology which highlight that "ageing well" and maintaining an active lifestyle is increasingly the responsibility of the individual (Rozanova, 2010; Katz, 2000) are not generally reflected in the articles from the Swedish news-press when the responsibility for reducing loneliness is addressed. The issue of loneliness among older people is, apart from only a few exceptions, addressed from the perspective of people who do not define themselves as "old" or "lonely", and are nevertheless engaged in working to improve the well-being of older people and reduce loneliness. The issue of reducing loneliness among older people is written from an outsider's perspective (see Uotila et al., 2010). Consequently, the concept of Aging Enterprise (Estes, 1979) is relevant in relation to the findings of this study, since responsibility for reducing loneliness and improving well-being among older people is discussed by professionals, politicians, journalists and persons active in civil society. It is mainly the people involved in discussing and working on reducing loneliness and improving well-being among older people that are constructed as actors with the ability to choose between actions in order to reduce loneliness among older people. Although the aims described in the articles are to include older people in social settings, the outsider's perspective can be seen as contributing to constructing old people as passive and not being able to conduct activities to reduce Ioneliness. Thus, the contrasting concept of including othering (Nilsson, 2008) becomes relevant in order to understand how the responsibility for reducing loneliness among older 
people is constructed in the Swedish news-press. However, although the responsibility to reduce loneliness is constructed as a matter for the Aging Enterprise and not older people, it does not exclude the possibility that older people could be constructed as responsible for reducing loneliness by people within the enterprise, in line with current ideals of active and successful ageing (van Dyk, 2014; Rozanova, 2010). To some extent, these ideals are explicitly expressed, mainly in the discourses of responsibility within seniors' organisations, where the acquiring of social relations is constructed as a matter for the individual. Implicitly, the responsibility of the individual is present in a majority of the articles as one of the main tasks addressed is how to make older people more socially active, with the aim of reducing Ioneliness. We would, nevertheless, claim that the manner in which the responsibility to reduce loneliness is constructed is mainly in line with the Aging Enterprise (Estes, 1979) and including othering (Nilsson, 2008) concepts and only to a minor extent alludes to ideals of active and successful ageing. Consequently, the people constructed by themselves and others as responsible for carrying out activities to reduce loneliness are those who work with policies, provision of eldercare and those being part of "society" - areas from which older people are excluded and in which they are constructed as recipients of help.

\section{Statement of funding}

The authors express gratitude for the generous funding by Norrköping Municipality Research and Development Fund (Norrköpings fond för forskning och utveckling), KS 2013/0721.

\section{Declaration of contribution of authors}

The first author designed the research, collected the data, participated in data analysis, was responsible for writing the article and approved the version to be published. The second author contributed throughout the data analysis, commented on different versions of the manuscript and approved the version to be published.

No conflict of interest.

\section{Notes}

${ }^{1}$ All excerpts are translated by authors. The excerpts in Swedish (the original language) are listed in the article's appendix.

${ }^{2}$ Greta, in Excerpt 7, is a fictional name since she is not a public person and has not had the opportunity to approve her participation in the study. All other persons appearing in the excerpts are public persons and therefore appear with their real names. 
${ }^{3}$ PRO is short for Pensionärernas riksorganisation. In English: The Swedish National Pensioners' Organisation.

\section{References}

Altheide, D. and L., Snow, R. P. (1979). Media Logic. London: Sage Publications.

Althusser L (1971) Lenin and Philosophy and Other Essays. London: New Left Books.

Birren, J. E. and Bengtson, V. L. (eds). (1988). Emergent Theories of Aging. New York: Springer. Bengtsson, T. (2010). Population Ageing - A Threat to the Welfare State? The Case of Sweden. Heidelberg: Springer-Verlag.

Berggren, H., Trägårdh, L., (2015). Är svensken människa? - Gemenskap och oberoende i det moderna Sverige. Stockholm: Norstedts.

Bergmann, J. (1998). "Introduction: Morality in Discourse". Research on Language and Social Interaction. 31, 279-94.

Burr V (2003) Social Constructionism. Second edition. London: Routledge.

Edley N (2001) Analysing masculinity: Interpretative repertoires, ideological dilemmas and subject positions. In Wetherell M, Taylor S and Yates S (eds), Discourse as Data. A Guide for Analysis. London: Sage.

Ekerdt, D. (1986). "The Busy Ethic: Moral Continuity Between Work and Retirement". The Gerontologist, 26, 239-44.

Estes, C-L. (1979). The Aging Enterprise. San Francisco: Jossey-Bass.

Estes, C-L. (1999). The Aging Enterprise Revisited, in Estes, C.L. and Minkler, M. (eds). Critical Gerontology Perspectives from Political and Moral Economy. Amityville, New York: Baywood Publishing Company. pp. 135-146.

Fealy, G., Mcnamara, M., Pearl Treacy, M. and Lyons, I. (2015). "Constructing ageing and age identities: a case study of newspaper discourses". Ageing \& Society. 32, 85-102.

Gadson, A. (2003). "Neither heart nor home: the (un)making of elder care responsibility". Journal of Aging Studies. 17, 17-29. 
Gentleman, A. (2016). "Loneliness 'forces older people into hospitals' and strains services, say senior doctors". The Guardian. Available online at:

https://www.theguardian.com/society/2016/feb/01/loneliness-forces-older-people-intohospitals-and-strains-services-say-senior-doctors [18/1-17]

Gilleard, C. and Higgs, P. (2007). Cultures of Ageing: Self, Citizen and the Body. Second edition. Harlow: Prentice Hall.

Jolanki, O, (2015). "Whose business is it anyway? Distributing responsibilities between family members and formal carers". Journal of Applied Linguistics and Professional Practice. 9, 31940.

Katz, S. (2000). "Busy bodies: Activity, aging, and the management of everyday life". Journal of Aging Studies. 14, 135-52.

Kessler, E-M., Rakoczy, K. and Staudinger, U., M. (2004). "The portrayal of older people in prime time television series: the match with gerontological evidence". Ageing \& Society. 24, 531-52.

Koskinen, S., Salminen, L. and Leino-Kilpi, H. (2014). "Media portrayal of older people as illustrated in Finnish newspapers". International Journal of Qualitative Studies on Health and Well-being. 9, 25304.

Laclau E and Mouffe C (2001). Hegemony and Socialist Strategy - Towards a Radical Democratic Politics. Second edition. London: Verso.

Laliberte Rudman, D. (2006). "Shaping the active, autonomous and responsible modern retiree: an analysis of discursive technologies and their links with neo-liberal political rationality". Ageing \& Society. 26, 181-201.

Loseke, D. (2003). Thinking about Social problems. Second edition. Hawthorne, New York: Aldine Transaction.

Lundgren, A. S. and Ljuslinder, K. (2011). "'The baby-boom is over and the ageing shock awaits': populist media imagery in news-press representations of population ageing". International Journal of Ageing and Later Life. 6, 39-71.

Markström, C., Ljuslinder, K. and Sjöström, S. (2011). "Konsensus och personifierade konflikter - Problembeskrivningar av äldreomsorg i svensk dagspress". Sociologisk Forskning. 48, 5-23. 
Monbiot, G. (2014). "The age of loneliness is killing us". The Guardian. Available online at: https://www.theguardian.com/commentisfree/2014/oct/14/age-of-loneliness-killing-us [18/1-17]

Mullins, L-C. (2007). Loneliness, in Birren, J. (ed). Encyclopedia of Gerontology New York: Elsevier Inc. pp. 93-98.

Nilsson, M. (2008). Our Elderly - On the Construction of Older People in Public Discourses [Eng. title]. Dissertation. Linköping University. Linköping.

O'Grady, S. (2015). "Loneliness as big a killer as obesity and as dangerous as heavy smoking". Express. Available online at: http://www.express.co.uk/life-style/health/563610/Lonelinessbad-obesity-and-heavy-smoking [18/1-17] Phillipson C (1998). Reconstructing Old Age. New Agendas in Social Theory. London: Sage. Pikhartova, J., Bowling, A. and Victor, C. R. (2016). "Is loneliness in later life a self-fulfilling prophecy?". Aging \& Mental Health. 20, 543-49.

Rosendale, M. (2007). "Loneliness: An Exploration of Meaning". Journal of the American Psychiatric Nurses Association. 13, 201-09.

Retriever: https://www.retriever.se/ [17/1-17]

Rozanova, J. (2010). "Discourse of successful aging in The Globe \& Mail: Insights from critical gerontology". Journal of Aging Studies. 24, 213-22.

Schirmer, W. and Michailakis, D. (2016). "Loneliness among the elderly as a social problem: The perspectives of medicine, religion and economy". Ageing \& Society. 36, 1559-79.

Socialstyrelsen (2016) Så tycker de äldre om äldreomsorgen 2016. Available at:

http://www.socialstyrelsen.se/publikationer2016/2016-10-2.

Solin, A. and Östman, J-O. (2015)." Introduction: Discourse and responsibility". Journal of Applied Linguistics and Professional Practice. 9, 287-94.

Spector, M., Kitsuse, J. (1973). "Social Problems: A Re-Formulation", Social Problems, 21, 14559.

Thompson, J. B. (2000). The Media and Modernity - A Social theory of the Media. Cambridge: Polity Press. 
Timonen, V. (2016). Beyond Successful and Active Ageing - a Theory of Model Ageing.

Chicago: Policy Press.

Townsend, P. (1981). "The structured dependency of the elderly: A creation of social policy in the twentieth century". Ageing \& Society, 1, 5-28.

Uotila, H., Lumme-Sandt, K. and Saarenheimo, M. (2010). "Lonely older people as a problem in society - construction in Finnish media". International Journal of Ageing and Later Life. 5, 103-30.

Victor, C. R., Scrambler, S. and Bond, J. (2009) The Social World of Older People: Loneliness and Social Isolation in Later Life. Buckingham: Open University Press.

Victor, C. R. Loneliness and Later Life - Concepts, Prevalence, and Consequences, in Sha'ked, A., Rokach, A. (eds) (2015). Addressing Loneliness - Coping, Prevention and Clinical Interventions. New York: Routledge.

Victor, C. R., and Sullivan, M. P. Loneliness and isolation, in Twigg, J., Martin, W. (eds) (2015). Routledge handbook of cultural gerontology. New York: Routledge.

van Dyk, S. (2014). "The appraisal of difference: Critical gerontology and the active-ageingparadigm". Journal of Aging Studies. 31, 93-103.

Warburton, J. and Jeppsson Grassman, E. (2011). "Variations in older people's social and productive ageing activities across different social welfare regimes". International Journal of Social welfare. 20, 180-91.

Westberg, N. (2012). Messages from Seclusion. A Sociological Study of Loneliness and Solitude. [Eng title]. Dissertation. Göteborg: Daidalos.

Wetherell, M. and Edley, N. (1999). "Negotiating hegemonic masculinity: Imaginary positions and psycho-discursive practices". Feminism Psychology. 9, 335-56.

Winther Jørgensen M. and Phillips L. (2002). Discourse Analysis as Theory and Method. London: Sage.

Wilińska M and Cedersund E (2010) “'Classic ageism' or 'brutal economy'? Old age and older people in the Polish media". Journal of Aging Studies 24, 335-343. 


\section{Appendix}

\section{Excerpt 1:}

Att arbeta förebyggande är en av förutsättningarna för att på ett bra sätt möta den demografiska utvecklingen. Att arbeta förebyggande är positivt för våra medborgare, det minskar eller senarelägger ett behov och en beroendesituation. Att arbeta förebyggande ger medborgarna möjlighet att bryta ensamhet och möta nya vänner. Förebyggande enheten inom omsorgsförvaltningen arbetar aktivt tillsammans med bland annat intresseorganisationer, regionen, Skåneidrotten, kultur och fritid samt frivilliga med olika former av aktiviteter och kulturupplevelser. [...] Personalen arbetar med målet ett gott liv, där de fyra hörnpelarna är social gemenskap, delaktighet, fysisk aktivitet och goda matvanor. Detta ger förutsättningar för en god hälsa och senarelägger en beroendeställning. Att få träffas och kanske bryta en oönskad ensamhet ger livslust, glädje och välbefinnande. (Kristianstadsbladet, 8 October, 2016)

\section{Excerpt 2:}

Ensamhet, oro och ångest präglar tillvaron för många äldre. Nu vill Socialstyrelsen att kommunerna förbättrar situationen för dessa individer. Socialstyrelsen har frågat alla äldre som har hemtjänst eller äldreboende om hur de mår och vad de tycker om hemtjänsten respektive äldreboendet. Resultatet visar att nästan var tionde, nio procent, har svåra besvär av ängslan, oro eller ångest. Något fler, 15 procent, säger att de ofta besväras av ensamhet. "Många är väldigt nöjda med sin hemtjänst eller med sitt äldreboende, men det finns en grupp som inte mår bra och som lider av dessa besvär. Det vi vill nu är att kommunerna uppmärksammar de här personerna och försöker se vad man kan göra för just dem", säger Stina Hovmöller, enhetschef på Socialstyrelsen.

Vad kan kommunerna göra åt ensamhet?

"Ensamhet kan ha många olika orsaker och äldre kan ha olika behov, men det är viktigt att kommunerna pratar med de som upplever dessa besvär och försöker förbättra situationen för just den individen", säger Stina Hovmöller. (Metro - Värmland, 19 October, 2016)

\section{Excerpt 3:}


- Det är glädjande att det är fortsatt positiva svar som visar att vårt fokus på värdegrund och möten ger resultat. Vi ligger väl till i jämförelse med både landet och länet, säger socialchefen Ann-Gret Sillén. Hon påpekar att det dock finns område som kan förbättras. "Vi behöver bli bättre på att den enskilde ska kunna påverka vilken tid man får hjälp. [...] Brukarens känsla av ensamhet är också en fråga som vi behöver fokusera lite extra på”. (Oskarshamns-Tidningen, 31 October, 2016)

Excerpt 4:

Kommunens budget inför de kommande åren ser inte ljus ut för oss äldre. Planerna på ökad byggnation när det gäller äldreboenden är inte mycket att hurra för. Behovet är stort redan i dag och de boenden som planeras kommer inte att räcka till. [...] Ni har också sparat in på verksamheten på de olika träffpunkterna genom att minska på personalen. [...] Ensamhet, undernäring och uttorkning är bland de största sjukdomarna hos oss äldre. Glöm inte bort oss! (Norrköpings-Tidningar, 14 October, 2016)

\section{Excerpt 5:}

Självvald ensamhet kan vara skön och rofylld. Ofrivillig direkt farlig, både för den fysiska och mentala hälsan. Utan relationer till andra riskerar människan att förlora fästet. Inom äldrevården, exempelvis, är det så mycket fokus på allt runtomkring, när det allra viktigaste för de äldre är relationerna, ögonkontakten, småpratet och kroppskontakten, säger han. [...] Effekterna av ensamhet och isolering som inte är självvald är generella för människan i stort. Förklaringen, menar han, är utvecklingsbiologisk. För att överleva på savannen bland rovdjuren för sisådär 100000 år sedan behövde urmänniskan hålla ihop. Avlägsnade du dig från gruppen var du i livsfara. (Helsingborgs Dagblad, 5 October, 2016)

\section{Excerpt 6:}

Att vara ofrivilligt ensam är att riskera sin hälsa. Ensamhet är en folksjukdom vi måste börja ta på allvar. I veckan publicerade Socialstyrelsen sin årliga undersökning "Så tycker de äldre om äldreomsorgen".

En undersökning som visar att de allra flesta äldre är nöjda med äldreomsorgen. Gott så. Men det finns andra delar i undersökningen som inte är lika positiva, som att en majoritet, 58 procent av de tillfrågade, uppger att de besväras av ensamhet. [...] Anledningen till att vi mår 
så dåligt av ensamhet har sin bäring i evolutionen. Tryggheten att ingå i en grupp har inneburit en sådan kraftig överlevnadsfördel att vi för hundratusentals år sedan utvecklade starka mekanismer för att söka gemenskap och undvika ensamhet. [...] Ofrivillig ensamhet är utbredd i alla åldrar, men ju äldre vi blir, desto mer utsatta blir vi. Det kan handla om att ens livspartner eller nära vänner gått bort, eller att kroppen inte tillåter samma rörlighet som förr, vilket gör att det är svårt att ta sig ut från det egna hemmet för att träffa andra människor. Men det går såklart att ändra på det här. Om vi vill. Om samhället vill.

Ett exempel finns hos hemtjänsten i Vännäs i Norrbotten. Där pågår ett försök med att erbjuda extra timmar med socialt stöd för vissa äldre som känner sig ensamma. (Arbetarbladet, 23 October, 2016)

\section{Excerpt 7:}

Boule bra medicin mot ensamhet i Nordmaling

I torsdags hade PRO Nordmalings boulesektion säsongspremiär i föreningens inomhusanläggning, där ett dussintal spelsugna pensionärer träffas måndagar och torsdagar. [...] "Boulen gör att jag kommer ut och slipper sitta ensam, att få träffa och prata med folk en stund gör att man känner sig nöjd. Sedan ger det lagom motion också och är inte alls tungsamt, därför kan man hålla på länge upp i åren”, säger Greta. (Västerbottningen, 13 October, 2016) 